\title{
Religious use of hallucinogenic fungi: A comparison between Siberian and Mesoamerican cultures
}

\author{
HARRI NYBERG
}

\begin{abstract}
NYBERG, H.1992: Religious use of hallucinogenic fungi: A comparison between Siberian and Mesoamerican cultures. - Karstenia 32:71-80.

The religious uses of hallucinogenic mushrooms in northern Eurasian and Mesoamerican cultures are compared. In northern Eurasia, some shamanistic cultures have used the Fly Agaric (Amanita muscaria (L.) Pers.); Mesoamericans, mainly mushrooms of the genus Psilocybe (Fr.) Kummer. The hallucinogenic potency of the former is due to isoxazole compounds and of the latter, psilocybine-type compounds. Despite similarities between the uses in these two cultural areas, there are also marked differences: the Fly Agaric did not seem to have been an object of religious, ritual veneration in northern Eurasia, whereas this was true for the Psilocybe mushrooms in Mesoamerica. This is suggested to be a result of the difference between these two mushroom groups in their pharmacological and clinical effects on man and also a result of vast cultural differences between the areas in question. The cultural and religious differences between northern Eurasian and Mesoamerican use of hallucinogenic fungi and the significance of these differences are discussed.
\end{abstract}

Keywords: Amanita muscaria, hallucinogenic fungi, Mesoamerican cultures, Psilocybe, shamanism, Siberian cultures

Department of Plant Biology, University of Helsinki, Viikki, SF-00710 Helsinki, Finland

\section{Introduction}

Religious use of hallucinogenic fungi has been repeatedly documented among shamanistic cultures in different parts of the world. In this paper, the use of these fungi by Siberian shamanistic cultures and by certain Mesoamerican Indian cultures are compared. There is an extensive documentation of the use of the Red Fly Agaric (Amanita muscaria (L.) Pers.) in Siberia, although the ethnologists have obviously been more interested in the shamanistic rites and their aims and performances, as well as in the mythology of the peoples studied. The use of the Fly Agaric by shamans or ordinary people in Siberia and its consequences have often been overlooked and usually described more or less briefly (e.g. Bogoras 1904-1909, Jochelson 1908, Lehtisalo 1924, Karjalainen 1927, Ohlmarks 1939, Siikala 1978). Studies on the Siberian use of the Fly Agaric have diminished during the recent years, with the notable exception of Saar (1991), who also presents some new data on the subject. However, the possible religious veneration of the Fly Agaric by the
Siberian peoples is a question which is largely neglected.

For some Mesoamerican ethnic groups, the use of hallucinogenic fungi was an essential part of the culture during the Spanish conquest, when it was for the first time observed by Europeans. It is obvious that this use of fungi had a long history behind it already at that time Fray Bernardino de Sahagún (1499-1590) mentioned the Aztec use of hallucinogenic fungi (Aztec teonanácatl) in his famous work "Historia General de las Cosas de Nueva España", also known as The Florentine Codex (de Sahagún, English transl. 1950-1963; hallucinogenic mushrooms are cited in Book 9: pp. 38-39; Book 10: pp. $12,20,37,49,55,88,173$; Book 11: pp. 120, 129, 130, Fig. 516). The Florentine Codex is bilingual (Spanish and Aztec) and is regarded also as the most important document on Classical Nahuatl (Aztec) language. As regards cultural anthropology, de Sahagún's research methods were far ahead of his time and even today his work is much more reliable than 
other Mexican documents from the same period (Ortiz de Montellano 1990).

This use of hallucinogenic fungi, especially species of the genus Psilocybe, was still practiced, but already about to vanish in the 1950 s, when it received the attention of the scientific world, mainly as a result of the field studies of R.G. Wasson and R. Heim in Mexico (see, for instance, Wasson 1957, Heim and Wasson 1958, Guzmán 1959, Wasson 1959, 1961). These discoveries, along with the growing interest in psychoactive drugs, led to a veritable stream of books and articles in which plants containing psychoactive or hallucinogenic compounds were described again and again. It is certainly no coincidence that all this happened when the 'hippie' movement was emerging; it created a supply and demand of many pseudoscientific writings. Some scientists also pondered the value of hallucinogenic substances as tools for research of religious experiences (for example, Staal 1975), or even encouraged their use. However, this trend, along with the recreational use of mushrooms, declined in the 1980s and, after all, recreational use has little to do with religion and thus falls outside the scope of this paper. However, the recreational use of psychoactive substances offers an interesting field for psychological and sociological studies.

Mushroom cult in Mesoamerica is evident from numerous so-called 'mushroom stones' dating from the Middle Preclassic Mayan period (1000-400 B.C.) to the Classic Mayan period (500-1000 A.D.) in southern Mexico and in Guatemala (de Borhegyi 1961, 1963, Lowy 1971, 1972, Morley et al. 1983). Also pottery mushrooms have been found in the Maya area (Mexico, Guatemala, El Salvador) dating from approximately the above-mentioned periods (de Borhegyi 1961, 1963). A well-known early (Mayan Preclassic) 'collection' of mushroom stones has been found from the Kaminaljuyú tombs near Guatemala City (de Borhegyi 1961, Morley et al. 1983). Stone engravings and frescoes representing or symbolizing mushrooms (according to the interpretation of Wasson 1980) occur also in the murals of Teotihuacán and other Aztec temples; however, engravings and paintings representing flowers of hallucinogenic plants seem to be much more common in the temples. Several XVI century Mexican codices have illustrations representing mushrooms (Heim \& Wasson 1958, Wasson 1980).

In this paper, I imply that although the religious use of mushrooms was found in both the Old and the New World, the ways of their uses and the rites, myths and ways of thought associated with them were essentially different. In comparing Siberian and Mesoamerican cultures I omit discussion of the well-known theory that the Indian and Iranian somal haoma was identical with the Fly Agaric (Wasson 1968); this very controversial question deserves a treatment of its own (Nyberg 1991a). The possible use of the Fly Agaric by ancient Norsemen (to explain the berserk rage) I have treated elsewhere (Nyberg 1991b). In comparative religion, the subject of the use of hallucinogenic fungi falls in the area of phenomenology, psychology and mysticism.

The effects of hallucinogenic fungi are caused by their chemical constituents whose occurrence, structure and toxicology can be studied by means of chemical and physiological methods. This is an interesting field of ethnopharmacology, other relevant fields being mycology (both the taxonomy and physiology of fungi), clinical toxicology and plant chemistry. The material for this study was provided by the extensive literature on the subject and the author's experience in plant chemistry.

\section{Pharmacological properties of the Red Fly Agaric, Amanita muscaria}

The Red Fly Agaric (Amanita muscaria) is a mushroom with wide distribution in the northern hemisphere. It is mycorrhizal with birch, pine and occasionally other coniferous and deciduous trees, of boreal and temperate climate, and is found in more southern latitudes only in montane forests. The genus comprises c. 100 species, of which at least the deathangel (Amanita phalloides (Fr.) Link.) and its white relatives (A. virosa (Fr.) Bert., A. verna (Bull.: Fr.) Roques) are deadly poisonous to man. The Fly Agaric is not fatal, because its poisons are isoxazole compounds, not related to the cyclopeptides of the deadly Amanita species. The Fly Agaric is an easily recognized, red-capped (some forms yellow-capped), large species, usually with white patches on the cap. Formerly it was used as a fly poison, a practice which is reflected in its vernacular name in many languages. The first toxic compound isolated from it, muscarine, was long held to be the main source of its poisonous properties, until the mushroom was found to contain far too small amounts of muscarine $(0.0003 \%)$ for it to be pharmacologically active (Bresinsky \& Besl 1985). Later other isoxazoles were found in larger amounts: ibotenic acid, muscazone and muscimol. Some strains contain c. $0.1 \%$ of ibotenic acid, but in other strains this is mostly replaced by muscazone (Wagner 1985).

Although Amanita muscaria is a well-known species indigenous to both Eurasia and America, it comprises numerous subspecies or geographical races, which differ in their isoxazole composition; 
moreover, variation occurs down to different clones of the mushroom. This explains the very varied responses in man observed in modern studies towards Fly Agaric consumption. The chemical, clinical and pharmacological properties of the Fly Agaric have been described by Singer (1978) and Bresinsky \& Besl (1985). Although the taxonomy of A. muscaria is still not fully known, a satisfactory review can be found in Singer (1978). The poisonous compounds are water-soluble, but not very rapidly extractable from the mushrooms, e.g. by boiling. In contrast, when the mushrooms are eaten or a broth made of them, the poisons dissolve and are absorbed rapidly from the stomach and the intestines into blood, and their effects are manifested after $30 \mathrm{~min}$ utes to 3 hours. The isoxazoles, especially muscimol (Schultes \& Hofmann 1980), pass through the human renal system almost intact, and thus it is possible to ingest them by drinking urine, human or reindeer, which also seem to eat the fungus (Furst 1976): this custom has been reported several times from northern Siberia (Bogoras 1904-1909, Jochelson 1908, Ohlmarks 1939, Saar 1991). Urine-drinking has probably been practiced because of the rarity of the Fly Agaric: this mycorrhizal mushroom is not likely to occur in treeless northern Siberia. It has thus also had certain commercial value in these parts.

Largest amounts of poisons occur in the mushroom cap, especially in the yellowish layer under the red pileipellis. Only small amounts can be found in the stipe. The main symptoms of Amanita muscaria poisoning (the Amanita pantherina-syndrome: Bresinsky \& Besl 1985) are lack of muscular coordination, moods fluctuating from bliss to rage, a sense of unreality, and emotional and also visual hallucinations (Singer 1978, Bresinsky \& Besl 1985). The symptoms often begin with a short period of sleep (Wasson 1968, Siikala 1978). A capacity to exceed one's normal physical powers has also been reported, for example, people are able to walk long distances in deep snow without getting tired, but when the mushroom effects end, exhaustion follows (Bogoras 1904-1909). In some users the Fly Agaric apparently causes a hang-over, and abstinence symptoms after long usage (Bogoras 1904-1909, Jochelson 1909), but this seems to depend on the individual. The nature of the hallucinations caused by the mushroom also seems to depend on the culture, and on psychological and physical characteristics of the user. In northern Siberia, the mushroom seems to have been used mainly by males. I will return later to the role of the Fly Agaric in shamanism.

\section{Pharmacological properties of Psilocybe mushrooms}

Most of the hallucinogenic mushrooms used in Mesoamerican cultures belong to the genus Psilocybe. This is a cosmopolitan genus with 144 species, of which 81 have been reported to contain hallucinogenic compounds (Bresinsky \& Besl 1985). Their taxonomy has been well monographed by Guzmán (1983). The seem to have been in use already in pre-Columbian (mainly in Mayan and Aztec) cultures in what are now Mexico, Guatemala and El Salvador. As early as in the 16th century de Sahagún (1950-1963) mentioned the use of teonanácatl, which Nahuatl word is often translated as 'divine flesh', 'flesh of the gods', (e.g. by Furst 1976), but a better translation is 'divine mushroom', 'dangerous mushroom' (Cooke 1977, Wasson 1980). This, however, was often confused by earlier scientists with the peyote cactus (Nahuatl peyotl, Lophophora williamsii (Lem.) Coulter; Ott 1978, Schultes \& Hofmann 1980). In the 1950s, thanks to the work of several eminent investigators (Schultes 1939, Reko 1949, Heim \& Wasson 1958, Ott 1978, Singer 1978, Schultes \& Hofmann 1980) it finally turned out that teonanácatl meant hallucinogenic mushrooms. The attitude of the Catholic church was from the beginning very unfavourable toward the use of the mushrooms, seen as a diabolic mimicry of the Holy Communion, and the church succeeded to suppress the use so that it survived only in remote mountainous areas. The traditional religious practice has been documented in the divinatory and magic rites of the Mazatec, Chinantec, Chatino, Zapotec, Mixe and Mixtec of Oaxaca, the Nahua of México, and possibly the Otomi of Puebla and the Tarascana of Michoacán (Schultes \& Hofmann 1980). Possible modern use has also been reported among the Chol and Lacandón Maya (Furst 1976). Linguistic evidence reveals much wider use in the whole area of ancient Aztec and Mayan cultures.

The most important species of Psilocybe in religious use have been $P$. aztecorum Heim, $P$. caerulescens Murr., P. hoogshagenii Heim, P. mexicana Heim, $P$. yungensis Singer \& Smith, $P$. zapotecorum Heim and $P$. (Stropharia) cubensis (Earle) Singer (Schultes \& Hofmann 1980). Complete lists were published by Schultes \& Hofmann (1980) and Guzmán (1983).

These mushrooms seem to prefer sites with high nitrogen content, and some of them are growing on cattle and deer dung. They are very variable in size, but usually small with a stipe of at most $10-15 \mathrm{~cm}$ and a more or less cone-shaped cap (hence the name 'liberty cap'). P. cubensis differs in habit from most 
other species; it is tall, robust and flat-topped. Their hallucinogenic compounds are psilocybine (the most important), psilocine and baeocystine. Some other related compounds are also found, but usually in small amounts (Schultes \& Hofmann 1980; Bresinsky \& Besl 1985). The psilocybine compounds are water-soluble indole derivatives, and have close relationships with tryptophane metabolism and auxintype plant hormones. As tryptamines they bear a resemblance to the active compounds of several hallucinogenic plants, for instance, ayahuasca (Banisteriopsis caapi (Spruce ex Griseb.) Morton), Syrian rue (Peganum harmala L.) and peyote (Lophophora williamsii). Close chemical relatives are also the ergot alkaloids of the ergot fungus (Claviceps purpurea (Fr.) Tulasne) and the synthetic, not naturally occurring LSD (lysergic acid diethylamide).

The symptoms caused by these fungi (mainly by psilocybine) have been called 'the Psilocybe syndrome' (Bresinsky \& Besl 1985). Psilocybine is a powerful compound causing hallucinations in man with doses as low as 4-8 $\mathrm{mg}$ or about two grams of dried fungi (Schultes \& Hofmann 1980). The effects are psychologically dramatic but do not affect man physiologically very greatly: symptoms pass in 6-10 hours without apparent aftereffects. The psychical symptoms vary according to the mental disposition and balance of the individual: feelings of euphoria or panic and consciousness of time, space and self change in a way which is very difficult afterwards to put into words; colours, sounds, smells and touch reach unusual intensities. Erotic feelings are often strong, and the person may experience imaginative traveling to distant places or times of the past or future. Luminous visual hallucinations are vivid especially in the dark: they may have geometric, organic or ornamental pattern shapes. It has been suggested that the human sacrificial victims of the Aztecs were willing to die because they were drugged with psilocybine (Bresinsky \& Besl 1985). However, the Aztecs thought that the continued existence of the world was guaranteed by sacrifice of human blood and hearts to the sun, and the souls of the sacrifice victims fared better in the afterlife than those of ordinary people (Ortiz de Montellano 1990). Thus it seems that no drugging was necessary, especially as the Aztec philosophical ideas were thoroughly permeated with the importance of fulfilling one's duty.

The curanderos who have consumed these mushrooms for decades have showed no abstinence symptoms between the seasons of use, and usually belonged to the oldestliving and mentally best-balanced individuals of their societies. No evidence exists of addiction or permanent psychic changes from psilo- cybine. In this, psilocybine resembles mescaline, as both seem to be lacking any element causing permanent damage to man.

\section{Use of the Fly Agaric in Eurasian shamanism}

Many documents on the use of Amanita muscaria in northern Siberia date back to the 17th century (Furst 1976). Use seems to have been both religious and recreational, and A. muscaria seems also to have been the only inebriant in the area before the availability of alcohol (Bogoras 1904-1909). When using A. muscaria, the psychological aim of the shaman is to reach an altered state of consciousness (ASC). Siikala (1978) defined several of these states and classified them; the religious use of A. muscaria is mainly connected with 'sacral institutional ASC'. However, the attaining of the ASC in Siberian shamanistic practices do not seem to depend on the use of the mushroom. The necessary prerequisites for a shaman to enter the ASC are a careful preparation of the séance (fasting, abstaining from sexual relations for a time, solitude, ritual donning of the shaman dress, and singing of hymns). The trance (ASC) is then usually attained with the help of rhythmic beating of the shaman's drum with increasing intensity. Mainly the rhythmic flow of impulses seems to influence the central nervous system of the shaman (Eliade 1964, Siikala 1978). But what is the attitude of shamans and their peoples towards A. muscaria and the reasons for its use?

Saar (1991) separates two regions of customary $A$. muscaria use. The first is West Siberia and the Taimyr Peninsula, where mushroom use has been reported among the Khanty (Ostyaks), Selkup (Southern Samoyeds), Nganasan (Taimyr Samoyeds) and Ket ('Yenisey Ostyaks'), with episodic use even now. The second area is the easternmost Siberia, including the Chukchi and Kamtchatka Peninsulas. The use of mushrooms has been reported among all peoples of the region: the Chukchi, Koryak, Itelmen ('Kamchadal'), Inuit, Yukagir, Even (Tungus) and even the Russian descendants of the earliest settlers in the area. Here the custom of A. muscaria consumption is still alive (Saar 1991). In some cultures, e.g. the Khanty, also women could be shamans and use the mushroom (Karjalainen 1927).

Bogoras (1904-1909) describes how A. muscaria leads to the appearance of the spirits of the Fly Agaric. The spirits bear the shape of actual mushrooms, and the user feels impelled to imitate them. The spirits are mischievous and play practical jokes on the user. They also ask for obeisance, which must 
be given, otherwise the person's life would be in danger. The spirits can take him to various worlds and show him visions. The Koryak call these spirits wapaq, a name used also to denote the mushroom itself (Furst 1976). Saar (1991) states that the mushroom spirits of the Khanty are half as tall as men and usually ask why the person has eaten the mushroom: this question must be answered. The person explains and then tells his desires and the spirits give the answer, in the form of a song or a narrative. The Forest Nenets believed that only those who were acquainted with the 'inner nature' of $A$. muscaria, could eat them "with luck", otherwise the spirits are not clearly visible, and they lead the shaman into darkness (Lehtisalo 1924). The Nenets shaman had to eat, in addition to the 'suitable' amount of mushroom caps, one halved mushroom cap, as this produced a spirit less powerful than the others and he will be able to follow them as they run swiftly in the same direction as the sun. The 'half-spirit' falls behind the others and makes it easier to follow the spirits.

Saar (1991) lists the reasons for the consumption of A. muscaria in Northern Eurasia as follows: 1) for communication with the souls of the dead or with spirits; 2) for treatment of diseases; 3) for naming a new-born child; 4) for making clear the cause of a dangerous situation and finding ways to overcome it; 5) for interpretation of dreams, prediction and fortunetelling, and seeing past events; 6) for visiting different worlds and flight over the earth (shamanistic journeys); 7) for creation of assistant spirits using $A$. muscaria as a mediator; 8 ) for increasing the shaman's courage; 9) for inspiration to recite songs or epics; 10) to increase bodily resistance to physical strain and 11) to call forth spirits of high status. According to the shamans, it is necessary to take into account the phase of development of the fruit body and the personality of the person consuming it. Also the dose and the form in which A. muscaria is consumed are important, but must be adjusted according to the user's purpose and to the 'nature' of the individual. Recreational use of A. muscaria has also at all times existed in Northern Eurasia (Bogoras 1904-1909, Jochelson 1909, Saar 1991). In the 19. century some ethnic groups preferred the use of the Red Fly Agaric as an inebriant instead of alcohol (Wasson 1968).

These descriptions suggest that the Fly Agaric itself was not an object of religious veneration, and no real mushroom cult existed in Siberia. The mushroom spirits are merely considered potentially dangerous helpers in the shaman's journey, with no evidence of any mushroom cult similar to that of the Mesoamerican cultures. Saar (1991) states that some Siberian peoples held the mushrooms to be supernatural beings, but it would perhaps be more correct to regard them as secondary tools. In fact, those shamans who did not need to utilize the mushroom as an ally were considered more powerful (Saar 1991). The eating of mushrooms does not seem to involve any specific rituals, and Eliade (1964) and Siikala (1978) share the view that only a weak shaman, i.e. a person whose psychical disposition to shamanism is not very suitable, had to use a chemical 'tool' to attain the necessary ASC. Eliade (1964) sees the use of mushrooms as a late development and even a 'degeneration' of shamanism; the high status of the shaman in society has caused many "less gifted" individuals to resort to mushrooms, which have the capacity to produce the necessary ASC, but in a crude and passive way (Eliade 1964).

\section{The Fly Agaric in North and Central America}

Amanita muscaria occurs through the vast area of North and Central America in all suitable habitats, though in the south only in mountainous areas. In the United States it fruits from early spring through late autumn, in Mexico from summer to autumn in the pine-oak forest belt (Ott 1976). In Mesoamerica the Fly Agaric is usually regarded as a poisonous and dangerous species (Lowy 1974). However, as the taxonomy of A. muscaria is incompletely known, it is not certain whether all clones belong to the same species in this area. Very little is known of its possible religious use outside the Old World: Wasson (1986a) reports its religious role among the Ojibwa Indians and its use by the Maya for divinatory purposes. Among the Quiché, Cakchiquel and Tzeltal Maya it seems to be associated with thunder and lightningbolts (Lowy 1974, Wasson 1986b). It seems that the association of certain mushrooms with thunder is widespread in different parts of the world, but little evidence is available to indicate that the Mesoamerican cultures were ever aware of the hallucinogenic properties of A. muscaria. However, certain mushroom stones of ancient Mesoamerica bear closer resemblance to A. muscaria than to Psilocybe: one striking example has been found in Patzcuaro (Michoacán, Mexico: Guzmán 1990). Also a ceramic bottle representing a human head with a patched mushroom emerging from the side of the forehead has been found; the mushroom bears a close resemblance to Amanita muscaria and the bottle is typical for the Mochica culture in Peru dating back to 200-500 A.D. (Niemelä 1984). Mushroom figures with patches on the cap occur also in Maya codices (Lowy 1972). It has been suggested that $A$. muscaria, which occurs 
throughout Guatemalan and Mexican pine forests, was once used by several tribes in Mesoamerica for religious purposes (Guzmán 1990).

\section{Religious use of Psilocybe fungi in Mesoameri- ca}

In contrast to the Eurasian cultures, a genuine mushroom cult in Mesoamerican cultures seems to have existed, and its beginnings can be traced to remote antiquity. The remarkable 'mushroom stones' (of stone or pottery) of the ancient Mayas and mural frescoes found in central Mexico are striking archeological evidence, the earliest 'mushroom stones' dating from the period 1000-300 B.C. (Mayan Early and Middle Preclassic: de Borhegyi 1961, 1963, Lowy 1971, Schultes 1972). Mushroom stones are found in all parts of Highland Guatemala and in the Petén province in northern Guatemala. They occur also in the Mexican states of Oaxaca, Tabasco, Veracruz and Chiapas, and in El Salvador (de Borhegyi 1961, 1963). They represent many different types, but the "stipe" is usually decorated with human or animal figures; their description and analysis are outside the scope of this article, but they seem to imply the existence of important mushroom cults among the ancient Maya.

Scripts from the early Conquest period (late 16th century) contain several descriptions of the importance of hallucinogenic mushrooms to Mexican religion and life. By far the most important contribution to the early knowledge of Mesoamerican mushroom cults is the huge work of de Sahagún (manuscript (The Florentine Codex) from 1578-80, English tr. by Anderson \& Dibble 1950-1963). Three types of hallucinogenic fungi are mentioned also by the famous Spanish physician, F. Hernández, sent to Mexico by the King of Spain (Hernández 1942-1946, orig. 1577: mushrooms mentioned in book 2/IX, Ch. 95). However, few later references to the use of hallucinogenic mushrooms in Mexico are to be found, until modern scientific interest 'discovered' the phenomenon anew, first in the 1930s, largely through the work of R.J. Weitlaner, B.P. Reko, J.B. Johnson and R.E. Schultes (Johnson 1939, Schultes 1939, 1940, 1978, V.A. Reko 1949, Heim \& Wasson 1958). In the 1950 s the task was taken up by R.G. Wasson, R. Heim, R. Singer and G. Guzmán; their results and the discovery of an extant mushroom cult in Mexico have been published many times, for instance by Wasson (1957), Heim \& Wasson (1958), Singer (1958), Schultes (1972) and Wasson (1980). The earliest Mexican and Spanish sources are well prsented by Heim \& Wasson (1958).

It is evident that specialists in the mushroom cult existed from the earliest times, and the use of hallu- cinogenic mushrooms in Mesoamerica was strictly ritualistic and under the control of 'professionals'. These people were in modern times called, in Spanish, curanderos (masc.) or curanderas (fem.), which reveals their main function: curing of illnesses. They had, however, other tasks also, such as finding lost or stolen property and predicting the future. Another name for the curers is sabio (masc.) or sabia (fem.), 'wise man, wise woman'. Quite often they were women. These are in literature also called 'shamans', but to me it seems that the latter name leads one astray, as the Mesoamerican 'wise person' does not in every respect resemble the Eurasian shaman. The Mazatec Indians, who have been most completely studied in this matter, divided the curers into three further categories (Estrada 1981): 1) on the lowest level is the sorcerer (Sp. brujo, Mazatec tji ?e) who can be evil and turn himself into an animal (nagual, Nahuatl nahualli) at night; 2) on the intermediate level is the curer (Mazatec cho ta xi v? $e^{\prime}$ nta), who uses massage, potions and a sacred language of his own; 3 ) in Huautla de Jiménez (Oaxaca, Mexico), the third and superior category was the 'Wise One and Doctor' (Mazatec cho ta chji ne), who does not use potions and does no evil. His power is in his ability to ingest and communicate with the mushrooms, euphemistically called 'saint children' (Mazatec ?nti xti santo), 'little one who springs forth' (Mazatec ?nti xi tjo), 'little saints' (Mazatec ?nti' sa nto) and 'little things' (Mazatec ?nti'tso jmi). Other edible or poisonous mushrooms are never called by these names (Estrada 1981).

The most comprehensively documented mushroom cult was found in the 1950s in the state of Oaxa$\mathrm{ca}$, southern Mexico. The Indian inhabitants of some mountain villages, especially the Zapotecs of San Agustín Loxicha, the Mixe of San Juan Mazatlán and the Mazatecs of Huautla de Jiménez, still actively practised the nocturnal mushroom séances ( $\mathrm{Sp}$. velada); the curandera of Huautla, María Sabina (born 1894), has especially attained worldwide fame (Heim \& Wasson 1958, Wasson 1958, Furst 1976). First she was introduced by Wasson (1957) under a pseudonym to protect the person and village against public interest. Her life and sacred chants have been published by Estrada (1981), himself a native Mazatec; and H. Munn, an American who married a Mazatec woman from Huautla, has contributed to our knowledge of María Sabina both by translating Estrada (1981) into English and studying the sacred language used in the mushroom cult (Munn 1973). The velada of María Sabina has also been recorded and the words and tunes published (Wasson et al. 1974).

The Mixe Indians in the eastern part of the state of Oaxaca, Mexico, have also used hallucinogenic Psilocybe mushrooms for divinatory and medicinal 
purposes up to the present time (Lipp 1990). In Mixe, these mushrooms are called na.shwiñ. mush and are further recognized under the following names: 1) pi.'tpa 'spindle whorl' or 'ene.ti.ic 'thunder's teeth' (Psilocybe mexicana, $P$. cordispora Heim), 2) atka:t 'judge' ( $P$. hoogshagenii) and ko:ng 'lord, governor' ( $P$. caerulescens). The Mixe consider these mushrooms to be all-knowing soothsayers, equated with the blood of Christ. According to the Mixe, illnesses originate in man's bones, and the mushrooms are the only 'medicine' able to penetrate the bones. They are said to grow only in sacred soil. According to the description of Lipp (1990), when they are found, they are first revered with kneeling and the lighting of candles, then plucked very carefully and taken to a house for treatment with copal (from Bursera bipinnata (DC) Engl. or some other woody plant yielding resins; author's comment) incense or to a church, and then they are used after three days. The partakers must abstain from sexual intercourse, from fowl or pig meat, mescal, eggs or vegetables during this period. After the mushrooms are eaten, on the next day chili peppers are eaten, but meat and alcohol are proscribed for one month. The mushrooms are always consumed in pairs, and the dosage varies according to the age and sex of the person. They are eaten in a lonely hut to prevent anyone from overhearing the conversation with the mushrooms; the mushrooms are also held to be sensitive to noise, and they stop 'speaking' when it occurs. Other hallucinogenic fungi found in divinatory use in this area are reported to be some species of the family Lycoperdaceae, and Scleroderma verrucosum Pers. (Ott et al. 1975). It is also interesting to note that in Chignahuapán (State of Puebla, Mexico), a church has been discovered to have been dedicated to a mushroom; this mushroom, carefully preserved in the church, was identified as Ganoderma lobatum (Schw.) Atk. (Guzmán et al. 1975, Guzmán 1990). This polypore has no hallucinogenic properties, but it is closely related to Ganoderma lucidum (Curt.: Fr.) Karst. which is considered especially in China and Japan to have medicinal properties (Stamets 1990). However, it is probable that the Indians of Chignahuapán had, at least formerly, practised a cult of sacred mushrooms (Guzmán 1990).

\section{Mushroom rituals of the Mazatecs in Huautla de Jiménez}

Munn (1973) describes the Mazatec mushroom velada as follows:

The Mazatec Indians eat the mushrooms only at night at absolute darkness. It is their belief that if you eat them in the daylight you will go mad... Usually several members of a family eat the mushrooms together: it is not uncommon for a father, mother, children, uncles and aunts to all participate in these transformations of the mind that elevate consciousness onto a higher plane. The mushrooms themselves are eaten in pairs, a couple representing man and woman that symbolizes the dual principle of procreation and creation. Then they sit together in their inner light, dream and realize and converse with each other, presences seated there together, their bodies immaterialized by the blackness, voices from without their communality... For everyone present the purpose of the session is a therapeutic catharsis... The psychedelic experience of the Mazatecs is inseparably connected with the curing of an illness; not only physical illness but spiritual and ethical problems. The mushrooms are eaten when something is wrong.

Both María Sabina herself (Estrada 1981) and Munn (1973) stress the importance of language in the mushroom cult. María Sabina describes the beginning phases of her call as follows (Estrada 1981):

I remember that I had a vision: some people appeared who inspired me with respect. I knew they were the Principal Ones of whom my ancestors spoke. They were seated behind a table on which there were many written papers. I knew that they were important papers. There were a number of Principal Ones, six or eight of them... Right away I heard a voice. A voice that was sweet but authoritarian at the same time. Like the voice of a father who loves his children but raises them strictly. A wise voice that said: "These are the Principal Ones". I understood that the mushrooms were speaking to me. I felt an infinite happiness. On the Principal Ones' table a book appeared, an open book that went on growing until it was the size of a person. In its pages there were letters. It was a white book, so white it was resplendent.

One of the Principal Ones spoke to me and said: "Maria Sabina, this is the Book of Wisdom. It is the Book of Language. Everything that is written in it is for you. The Book is yours, take it so you can work". I exclaimed with emotion: "That is for me. I receive $i t^{\prime \prime} .$. I limited myself to contemplating it and, at that moment, I began to speak. Then I realized that I was reading the Sacred Book of Language. My Book. The Book of the Principal Ones.

I had attained perfection. I was no longer a simple apprentice. For that, as a prize, as a nomination, the Book had been granted me. When one takes the saint children, one can see the Principal Ones. Otherwise not. And it's because the mushrooms are saints: they give wisdom. Wisdom is Language. Language is in the Book. The Book is granted by the Principal Ones. The Principal Ones appear through the great power 
of the children. I learned the wisdom of the Book. Afterwards, in my later visions, the Book no longer appeared because I already had its contents in my memory.

The curing ceremony that María Sabina used to cure her sister is described as follows:

The vigil... I conducted as the ancient Mazatecs did. I used candles of pure wax; flowers, white lilies and gladiolas (all kinds of flowers can be used as long as they have scent and color); copal and San Pedro (ground-up tobacco (Nicotiana rustica L.) mixed with lime and sometime also with garlic; author's comment) as well.

In a brazier I burned the copal and with the smoke incensed the saint children that I held in my hands. Before eating them, I spoke to them. I asked them for favor. That they bless us, that they teach us the way, the truth, the cure. That they give the power to follow the tracks of evil in order to be done with it. I said to the mushrooms: "I will take your blood. I will take your heart. Because my conscience is pure, it is clean like yours. Give me truth. May Saint Peter and Saint Paul be with me". When I felt dizzy, I blew out the candles. The darkness serves as a background for what is seen.

The person who gathers or uses Psilocybe mushrooms in the way decribed above must abstain from sexual relations and avoid any connection with corpses, dead animals or any decomposing matter.

The language (the sacred chants) of María Sabina is interestingly full of symbolism which is not easily understood. Moreover, the language is not the same in all cases (Estrada 1981). An example of the chants runs as follows (the original Mazatec translated into English by Estrada 1981):

I am a woman who shouts, says

I am a woman who whistles, says

I aI am a woman who thunders, says

I am a woman who plays music, says

I am a spirit woman, says

I am a woman who shouts, says

Ah, our Jesus Christ, says

Ah, our Jesus, says

Our Saint Peter woman, says

Our Saint Peter woman, says

Our Ustandi woman, says

Our shooting star woman, says

Our shooting star woman, says

Our whirling woman of colors, says

The Mazatec used in the chants is much richer in vocabulary than the usual conversational language, and much of it is incomprehensible to ordinary people; this, of course, is a common trait to shamanistic sacred languages everywhere (Eliade 1964). The word 'says' repeated after each strophe refers to the mushrooms; it is the sacred mushroom who 'says' everything. In the chants, Christian holy persons and native Mazatec characters (for instance, the Lord of the Mountains, Mazatec Chicon Ninto) appear together. The syncretistic features of the cult are manifest, although the Indian concepts are the prevailing ones, being woven together with Christianity only in comparatively modern times.

\section{Conclusions}

It seems that, to our present knowledge, religious use of hallucinogenic fungi has occurred in two large areas in the world: northern Eurasia and Mesoamerica. Outside these areas, the evidence is inconclusive, although Wasson $(1968,1986 a)$, especially, sought to prove fungi's former use also among the early IndoAryans and Greeks. I also disagree with the theory enthusiastically put forward by Wasson (Wasson 1961, 1986a), and favoured by some other scholars, such as La Barre $(1972,1990)$, that hallucinogens were once indeed the source of all religion and of the evolution of human culture in general. One should take seriously the warnings of Weil (1978), concerning psychedelic mycophagy, and Naranjo (1990), who comments on Wasson's ideas on the origins of religion. However, it is true that the shamanistic world-view seems to be a very old way for man to arrange his relationship both to the visible and the supernatural world (Furst 1976). On the other hand, it is significant that Furst himself does not openly commit himself to 'the Wasson theory' even in his published reminiscences of Wasson (Furst 1990).

It is evident that the use of hallucinogenic or if we prefer to use the word coined by Ruck and Wasson (Wasson 1978, Wasson 1986a), entheogenic - mushrooms has many common characteristics both in northern Eurasia and Mesoamerica: both cultural areas have used them for similar purposes. But there are also profound differences: in northern Eurasia the mushrooms themselves have not been objects of veneration, while in Mesoamerican cultures this has been the rule. In my opinion, this contrast is mainly a result of the difference in the mind-altering properties between Amanita muscaria and the Psilocybe mushrooms, which, in turn, derives from the fact that these two groups contain totally different hallucinogenic compounds.

We also have to take into account the profound cultural differences between Mesoamerican and Siberian cultures. In Mesoamerica, the religious use of hallucinogenic fungi evolved among culturally ad- 
Table 1. Comparison between the religious use of hallucinogenic fungi in Siberia and Mesoamerica

\begin{tabular}{|c|c|}
\hline MESOAMERICA & SIBERIA \\
\hline $\begin{array}{l}\text { mushrooms: mainly } \\
\text { Psilocybe, also others }\end{array}$ & $\begin{array}{l}\text { mushrooms: Ama- } \\
\text { nita muscaria only }\end{array}$ \\
\hline $\begin{array}{l}\text { use strictly ritual } \\
\text { and obligatory }\end{array}$ & $\begin{array}{l}\text { use not ritual or } \\
\text { obligatory }\end{array}$ \\
\hline $\begin{array}{l}\text { use limited to profes- } \\
\text { sional shamans }\end{array}$ & $\begin{array}{l}\text { use not limited } \\
\text { to professionals }\end{array}$ \\
\hline no recreational use & $\begin{array}{l}\text { recreational use } \\
\text { common }\end{array}$ \\
\hline $\begin{array}{l}\text { mushrooms regarded } \\
\text { as divine or a manifes- } \\
\text { tation of divinity }\end{array}$ & $\begin{array}{l}\text { mushrooms regar- } \\
\text { ded as a tool or as } \\
\text { as an ally }\end{array}$ \\
\hline mushrooms sacred & mushrooms not sacred \\
\hline $\begin{array}{l}\text { mushrooms not } \\
\text { subject to trade }\end{array}$ & $\begin{array}{l}\text { mushrooms have } \\
\text { commercial value }\end{array}$ \\
\hline $\begin{array}{l}\text { use not revealed to } \\
\text { outsiders }\end{array}$ & $\begin{array}{l}\text { no special secrecy } \\
\text { in use }\end{array}$ \\
\hline $\begin{array}{l}\text { the mushrooms them- } \\
\text { selves speak to } \\
\text { the shaman }\end{array}$ & $\begin{array}{l}\text { the mushroom calls } \\
\text { forth spirits; the shaman } \\
\text { speaks with the spirits }\end{array}$ \\
\hline
\end{tabular}

vanced agriculturalist peoples with a centralized government, which emphasized the role of the rulers, gods, shrines and a priestly class. The use of hallucinogenic fungi in modern times can be considered a remnant of an official religious system, which disintegrated after the Spanish conquest. In contrast, the Siberian cultures were culturally at a lower level with more diffuse and variable religious ideas and with a subsistence economy based on hunting, fishing and reindeer-breeding. This formed the basis of the development of shamanism in its 'genuine' form (i.e. in the sense described by Eliade 1964). Moreover, the Siberian peoples were mostly nomadic or seminomadic, and this explains the wide distribution of the use of Amanita muscaria in northern Eurasia and the cultural similarities of the peoples concerned, from the Lapps in the west to the Chukchi and Koryak in the east. The use of Psilocybe fungi in Mesoamerica seems, in contrast, to have been confined to relatively small areas. However, the difference in the active hallucinogenic compounds of Amanita muscaria and
Psilocybe must also have been an important factor in explaining the differences between the religious use of fungi in Mesoamerica and Siberia.

Acknowledgements. I am grateful to Dr. Tuomo Niemelä (Department of Botany, University of Helsinki) for critical reading of the manuscript and many useful comments and suggestions. I also wish to thank Ms. Sirkka Sällinen and to Ms. Marjatta Rautiala (Botanical Library, Department of Botany, University of Helsinki) for their patience in helping me to find the often not so easily available sources for my work.

\section{References}

Bogoras, W. 1904-1909: The Chukchee. The Jesup North Pacific Expedition. - Mem. Amer. Mus. Nat. Hist. 7:1-733. E.J. Brill, Leiden - G.E. Stechert, New York.

de Borhegyi, S.F. 1961: Miniature mushroom stones from Guatemala. - Amer. Antiquity 26:498-504.

de Borhegyi, S.F. 1963: Precolumbian pottery mushrooms from Mesoamerica. - Amer. Antiquity 28:328-338.

Bresinsky, A. \& Besl, H. 1985: Giftpilze. Ein Handbuch für Apotheker, Ärtzte und Biologen. - 295 pp. Wissenschaftliche Verlagsgesellschaft, Stuttgart.

Cooke, R.C. 1977: Fungi, man and his environment. - 144 pp. Longman, London.

Eliade, M. 1964: Shamanism: Archaic techniques of ecstacy. 610 pp. Pantheon Books, New York.

Estrada, A. 1981: María Sabina: Her life and chants. - 239 pp. Ross-Erikson, Santa Barbara, CA.

Furst, P.T. 1976: Hallucinogens and culture. - 194 pp. Chandler \& Sharp, Novato, CA.

Furst, P.T. 1990: 'Vistas beyond the horizon of this life': Encounters with R. Gordon Wasson. In: Riedlinger, T.J. (ed.), The sacred mushroom seeker: 67-81. - Dioscorides Press, Portland, OR.

Guzmán, G. 1959: Sinopsis de los conocimientes sobre los hongos alucinógenos mexicanos. - Bol. Soc. Bot. de México 24:14-34.

Guzmán, G. 1983: The genus Psilocybe: A systematic revision of the known species including the history, distribution and chemistry of the hallucinogenic species. - Beih. Nova Hedw. 74:1-439.

Guzmán, G. 1990: Wasson and the development of mycology in Mexico. In: Riedlinger, T.J. (ed.), The sacred mushroom seeker: 83-110. - Dioscorides Press, Portland, OR.

Guzmán, G., Wasson, R.G. \& Herrera, T. 1975: Una iglesia dedicada al culto de un hongo "Nuestro Señor del Honguito", en Chignahuapán, Puebla. - Bol. Soc. Mexicano Mic. 9:137-147.

Heim, R. \& Wasson, R.G. 1958: Les champignons hallucinogènes du Mexique. Études ethnologiques, taxonomiques, biologiques, physiologiques et chimiques. Arch. Mus. Nat. d'Hist. Nat., 7e Sr. 6:1-322 + 36 plates. Paris.

Hernández, F. 1942-1946: Historia de las plantas de Nueva España, Vols 1-3. Imprenta Universitaria, México. (Orig. 1577, in Latin; quoted after Heim \& Wasson (1958) and Ortiz de Montellano (1990).

Jochelson, W. 1908: The Koryak. The Jesup North Pacific Expedition. - Mem. Amer. Mus. Nat. Hist. 6:1-842. E.J. Brill, Leiden - G.E. Stechert, New York. 
Johnson, J.B. 1939: The elements of Mazatec witchcraft. Ethnol. Studies (Gothenburg) 9 (1939):128-150.

Karjalainen, K.F. 1927: Die Religion der Jugra-Völker III. Folklore Fellows Commun. 63:1-352.

La Barre, W. 1972: Hallucinogens and the origin of religion. In: Furst, P.T. (ed.), Flesh of the gods: The ritual use of hallucinogens: 261-278. - George Allen \& Unwin, London.

La Barre, W. 1990: My friend Gordon. In: Riedlinger, T.J. (ed.), The sacred mushroom seeker: 147-149. - Dioscorides Press, Portland, OR.

Lehtisalo, T. 1924: Entwurf einer Mythologie der Jurak-Samojeden. - Mém. Soc. Finno-Ougr. 53:1-171.

Lipp, F.J. 1990: Mixe concepts and uses of entheogenic mushrooms. In: Riedlinger, T.J. (ed.), The sacred mushroom seeker. pp. 151-159. - Dioscorides Press, Portland, OR.

Lowy, B. 1971: New records of mushroom stones from Guatemala. - Mycologia 63:983-993.

Lowy, B. 1972: Mushroom symbolism in Maya codices. Mycologia 64:816-821.

Lowy, B. 1974: Amanita muscaria and the thunderbolt legend in Guatemala and Mexico. - Mycologia 66:188-191.

Morley, S.G., Brainerd, G.W. \& Sharer, R.J. 1983: The ancient Maya, 4th Ed. - 708 pp. Stanford University Press, Stanford, CA.

Munn, H. 1973: The mushrooms of language. In: Harner, MJ. (ed.), Hallucinogens and shamanism: 86-122. - Oxford University Press, London.

Naranjo, C. 1990: A posthumous 'encounter' with R. Gordon Wasson. In: Riedlinger, T.J. (ed.), The sacred mushroom seeker. pp. 177-181. - Dioscorides Press, Portland, OR.

Niemelä, T. 1984: Tapoja, taikoja ja uskomuksia. In: Härkönen, M. (main ed.), Sienestäjän tietokirja: 15-18. - Valitut Palat-Reader's Digest, Helsinki.

Nyberg, H. 1991a: The problem of the Aryans and the Soma: Botanical evidence. - Paper read at the Conference on Archeological and linguistic Approaches to Ethnicity in Ancient South Asia,Toronto 4-6 Oct. 1991.

Nyberg, H. 1991b: Röd flugsvamp — orsaken till bärsärkaraseriet? - Jordstjäman 12:7-10.

Ohlmarks, A. 1939: Studien zum Problem des Schamanismus. - 395 pp. C.W.K. Gleerup, Lund, Ejnar Munksgaard, Kopenhagen.

Ortiz de Montellano, B.R. 1990: Aztec medicine, health and nutrition. - 308 pp. Rutgers University Press, New Brunswick, NJ.

Ott, J. 1976: Hallucinogenic plants of North America. 161 pp. Wingbow Press, Berkeley, CA.

Ott, J., Guzmán, G., Romano, J. \& Díaz, J.L. 1975: Nuevos datos sobre los supuestos licoperdaceos psicotrópicos y dos casos de intoxicación provocados por hongos del genero Scleroderma en México. Bol. Soc. Mexicano Mic. 9:67-76.

Reko, V.A. 1949: Magische Gifte. Rausch- und Betäubungsmittel der neuen Welt, 3. Aufl. - 175 pp. Ferdinand Enke Verlag, Stuttgart. (First edition 1936).

Saar, M. 1991: Ethnomycological data from Siberia and northeast Asia on the effect of Amanita muscaria. - J. Ethnopharmacol. 31:157-173.

de Sahagún, Fray B. 1950-1963: The Florentine Codex. General history of the things in New Spain. 14 vols. English tr. by A.J.O. Anderson \& C.E. Dibble. The School of American Research and the University of Utah, Santa Fé, NM. - Cited parts: Book 9 (= Vol. 10) - The merchants. 1959, 97 pp.; Book 10 (= Vol. 11) - The people. 1961, 197 pp.; Book 11(= Vol. 12) - Earthly things. 1963, 297 pp.
Schultes, R.E. 1939: Plantae Mexicanae II. The identification of teonanacatl, a narcotic basidiomycete of the Aztecs. - Bot. Mus. Leafl. Harvard Univ. 7:37-54.

Schultes, R.E. 1940: Teonanacatl, the narcotic mushroom of the Aztecs. - Amer. Anthropologist 40:698-715.

Schultes, R.E. 1972: An overview of hallucinogens in the Western Hemisphere. In: Furst, P.T. (ed.), Flesh of the gods: The ritual use of hallucinogens: 3-54. - George Allen \& Unwin, London.

Schultes, R.E. 1978: Evolution of the identification of the sacred hallucinogenic mushrooms of Mexico. In: Ott, J. \& Bigwood, J. (eds.), Teonanacatl: Hallucinogenic mushrooms of North America: 25-41. - Madrona Publishers, Seattle, WA

Schultes, R.E. \& Hofmann, A. 1980: The botany and chemistry of hallucinogens, 2nd ed. $-437 \mathrm{pp}$. Charles C. Thomas, Springfield, Ill.

Siikala, A.-L. 1978: The rite technique of the Siberian shaman. - Folklore Fellows Commun. 220:1-385.

Singer, R. 1958: Mycological investigations on teonanácatl, the Mexican hallucinogenic mushroom I: The history of teonanácatl, field work and culture work. - Mycologia $50: 239-261$.

Singer, R. 1978: Hallucinogenic mushrooms. In: Rumack, B.H. \& Salzman, E. (eds.), Mushroom poisoning: Diagnosis and treatment: 201-214. - CRC Press, West Palm Beach, Fla.

Staal, F. 1975: Exploring mysticism. - 224 pp. Penguin Books, Harmondsworth

Stamets, P. 1990: A discussion on the cultivation of Ganoderma lucidum (Curtis: Fr.) Karst., the reishi or ling zhi mushroom of immortality. - Mcllvainea 9(2):40-50.

Wagner, H. 1985: Pharmazeutische Biologie 2: Drogen und ihre inhaltsstoffe, 3. Aufl. - 496 pp. Gustav Fischer Verlag, Stuttgart.

Wasson, R.G. Great adventures. Seeking the magic mushroom. - Life International 22(2) (June 10,1957): 44-60.

Wasson, R.G. 1959: The hallucinogenic mushrooms of Mexico: An adventure in ethnomycological investigation. - Transact. NY Acad. Sci. 21:325-339.

Wasson, R.G. 1961: The hallucinogenic fungi of Mexico: An inquiry into the origins of the religious idea among primitive peoples. - Bot. Mus. Leafl. Harvard Univ. 19:137-162.

Wasson, R.G. 1968: Soma: Divine mushroom of immortality. - 381 pp. Harcourt Brace Jovanovich, New York.

Wasson, R.G. 1980: The wondrous mushroom: Mycolatry in Mesoamerica. - 248 pp. McGraw-Hill, New York.

Wasson, R.G., Cowan, G., Cowan, F. \& Rhodes, W. 1974: María Sabina and her Mazatec mushroom velada. Text, tunes and recordings. - Harcourt Brace Jovanovich, New York.

Wasson, R.G. 1986a: Persephone's quest. In: Wasson, R.G., Kramrisch, S., Ott, J. \& Ruck, C.A.P. (eds.), Persephone's quest: Entheogens and the origins of religion: 17-81. Yale University Press, New Haven, CT.

Wasson, R.G. 1986b: Lightningbolt and mushroom. In: Wasson, R.G., Kramrisch, S., Ott, J. \& Ruck, C.A.P. (eds.), Persephone's quest: Entheogens and the origins of religion: 83-94. - Yale University Press, New Haven, CT.

Weil, A. 1978: Reflections on psychedelic mycophagy. In: Ott, J. \& Bigwood, J. (eds.), Teonanacatl: Hallucinogenic mushrooms of North America; pp. 149-155. - Madrona Publishers, Seattle, WA.

Received on 14 February 1992 